\title{
Effect of a Free-Living Marine Nematode (Diplolaimella chitwoodi) on Detrital Carbon Mineralization*
}

\author{
Stuart Findlay** and Kenneth R. Tenore \\ Skidaway Institute of Oceanography, Post Office Box 13687, Savannah, Georgia 31406, USA
}

\begin{abstract}
Natural densities $\left(10^{6}\right.$ nematodes $\left.\mathrm{m}^{-2}\right)$ of the free-living marine nematode Diplolaimella chitwoodi increased maximum rates of carbon mineralization of Gracilaria detritus by $300 \%$; lower densities $\left(10^{4} \mathrm{~m}^{-2}\right)$, by $100 \%$. In the presence of nematodes increased mineralization was observed for 2 different particle sizes oof Gracilaria detritus, 63 to 100 and 250 to $308 \mu \mathrm{m}$. In the absence of nematodes, there were only slight differences in mineralization rates between the 2 particle sizes. Nematodes also increased the rate of mineralization of Spartina detritus but to a lesser degree $(50 \%)$. Meiofaunal nematodes can significantly affect benthic carbon flow by such an effect on the rate of detritus mineralization.
\end{abstract}

\section{INTRODUCTION}

Detritus is a major energy source for most marine benthic systems. Salt marshes and submerged angiosperms are very productive but little of this organic material is consumed while the plants are alive (e.g. Teal, 1962; Fenchel, 1977). Macroalgae, although more susceptible to direct grazing, may also be a significant source of dead organic matter. While sedimentation inputs to the benthos are becoming known, the fate of organic matter once it enters benthic systems is poorly understood. Rates of oxygen uptake by the benthos have been measured (Pamatmat, 1977) but these shed little light on what mechanisms are important in the transfer of detrital carbon to benthos.

Microbes, meio- and macrofauna assimilate detrital carbon and subsequently mineralize organic $\mathrm{C}$ to $\mathrm{CO}_{2}$. The proportion of carbon incorporated into tissue relative to that mineralized to $\mathrm{CO}_{2}$ will affect benthic production because, once mineralized, detrital carbon is essentially lost as an energy source for the benthos (Christian and Wetzel, 1978). This represents a com-

\footnotetext{
- Supported by NSF Grant (OCE78-25862) to Kenneth R. Tenore

- Present address: Institute of Ecology, University of Georgia, Athens, Georgia 30602, USA
}

petition between 'wasteful' (with respect to macrofaunal production) mineralization and 'useful' assimilation/production. The ratio of production to organic carbon mineralization ( $\mathrm{P}: \mathrm{O}$; Tenore and Hanson, 1980) is a benefit:cost ratio for the system. Increasing the rate of mineralization of detritus relative to the assimilation will tend to decrease benthic production.

Microbes probably mineralize the major portion of detrital carbon sedimenting to the benthos but direct measurements have not been made. Partitioning of benthic oxygen uptake implies that bacteria are responsible for the majority of oxygen consumption ( $\approx$ mineralization) (e.g. Smith et al., 1972). Therefore, changes in microbial metabolic rates affect mineralization rates. In particular, increasing microbial activity will increase losses of organic carbon thereby decreasing the amount of food available to other consumers. Conversely, it can be argued that microbial activity converts refractory detritus into nutritionally available food (e.g. Ward and Cummins, 1979) but the general importance of microbial biomass in detritivore nutrition is questionable (Cammen, 1980).

Microbial activity, and therefore detritus mineralization, is generally increased by warmer temperatures and greater availability of oxygen and nitrogen (Haines and Hanson, 1979). Overall, detritus derived from vascular plants decomposes more slowly than detritus derived from seaweeds due to lower $\mathrm{N}$ content 
and a larger proportion of 'recalcitrant' material such as lignin and humic acids in vascular plants (Godshalk and Wetzel, 1978). For any particular detritus type and conditions, microbial activity is greater for detritus of smaller particle size (Gosselink and Kriby, 1974) probably due to the greater surface/volume ratio for smaller particles. Temporal aspects of detritus dynamics may confuse these generalities because microbial activity reaches its maximum rate sooner for 'available' detritus such as seaweeds and relatively later for vascular plant detritus (Tenore, 1977; Tenore and Hanson, 1980). While detrital type, N-content and particle size directly affect microbial activity, other organisms may directly and/or indirectly influence rates of decomposition.

Macrofauna generally increase rates of detritus degradation (Fenchel, 1970; Hargrave، 1970; Briggs et al., 1979). Macrofauna may indirectly influence microbial activity via bioturbation, thus increasing oxygen availability and bringing up nutrients from deeper sediment layers. Aside from bioturbation, some macrofauna physically shred large fragments of detritus thereby decreasing particle size and increasing rates of decomposition (Robertson and Mann, 1980). Apart from these physical changes associated with macrofaunal grazing, it has been postulated that grazing, by removing senescent cells, may maintain the microbial community in log phase of growth (Cooper, 1973; Fenchel, 1977). Direct confirmation of this mechanism for increasing microbial activity is lacking but it is a reasonable explanation for increased decomposition in the presence of macrofauna or grazers. Conversely, direct macrofaunal respiration of detrital carbon is probably a minor component of total $\mathrm{C}$ flow in benthic systems. For example, the presence or absence of Capitella, a non-bioturbator, did not significantly affect oxidation rates in flow-through microcosms (Tenore, 1977).

While several macrofaunal species are known to affect rates of decomposition, there are very few similar studies with meiofauna. Grazing by protozoans increased bacterial activity and detritus mineralization (Barsdate et al., 1974). Conversely, ciliates did not affect mineralization of Gracilaria detritus but did increase incorporation of detritus by Nereis succinea (Briggs et al., 1979). Nematodes increase orthophosphate regeneration (Tietjen, 1980), which implies that nematodes might enhance mineralization of detritus.

Meiofauna probably are an important component of benthic energy flow because of their high abundance and metabolic rates (Coull and Bell, 1979). Moreover, meiofauna function at temporal and spatial scales similar to the microbes, allowing close coupling between microbes and meiofauna. Their rapid turnover rates would enable meiofauna to respond quickly to changes in microbial biomass or activity. By the same token, this coupling implies that meiofauna grazing or physical activity may exert a significant positive or negative effect on microbial biomass and turnover. Also, meiofauna are small enough to allow them to directly and perhaps selectively feed on specific microbes, thus changing the composition of the microbial community. For these reasons, one might expect meiofauna in general, and particularly nematodes, the dominant taxon, to affect microbial activity and thereby affect detrital decomposition.

Therefore, ${ }^{14} \mathrm{C}$ tracer techniques were used to explore the possible effect of the meiobenthic nematode Diplolaimella chitwoodi on rates of detrital carbon mineralization. We examined the effect of (1) nematode density on mineralization rate of Gracilaria and Spartina detritus; (2) nematodes on mineralization rates of 2 particle sizes.

\section{METHODS}

Detritus was homogeneously labelled with ${ }^{14} \mathrm{C}$ by growing Gracilaria or Spartina in the presence of ${ }^{14} \mathrm{CO}_{2}$ (Tenore et al., 1979). Dried plant material was ground in a Wiley mill to pass a $250 \mu \mathrm{m}$ screen. Immediately before use, detritus was aged for $3 \mathrm{~d}$ in $100 \mathrm{ml}$ of autoclaved seawater $\mathrm{g}^{-1} \mathrm{dry}$ wt detritus. Two $\mathrm{ml}$ of filtered $(3 \mu \mathrm{m})$ seawater from nematode cultures were added to provide a microbial inoculum. Detritus for the particle size experiment was aged, freeze-dried, and ground with mortar and pestle. The size classes, 63 to $100 \mu \mathrm{m}$ and 250 to $308 \mu \mathrm{m}$, were separated by sieving.

The nematode Diplolaimella chitwoodi (Monhysteridae) was maintained on Gerbers Mixed Cereal (Pablum) in $75 \mathrm{~cm}^{2}$ tissue culture flasks. Only cultures in late log phase of growth were used in experiments. Nematodes were separated from the Pablum by a modified Baermann extraction (Sikora et al., 1977) resulting in a clean suspension of worms. Various volumes of this worm suspension were added to experimental chambers to give the required density of nematodes.

Flow-through chambers (Tenore et al., 1977) with an area of $32 \mathrm{~cm}^{2}$ and a volume of $203 \mathrm{~cm}^{3}$ were layered with fine sand $(2 \mathrm{~cm}$ ) and $300 \mathrm{mg}$ dry wt $(50 \mathrm{mg}$ dry wt for particle size experiment) ${ }^{14}-\mathrm{C}$ labelled detritus. Worms were added and the chambers sealed. Autoclaved, aerated seawater was pumped through at $\sim 4$ mls $\min ^{-1}\left(\sim 28\right.$ turnovers $\left.d^{-1}\right)$. All experiments were conducted at $20^{\circ} \pm 1^{\circ}$ and in the dark for $6 \mathrm{~d}$. Two replicates were run for each treatment.

Mineralization rate (organic ${ }^{14} \mathrm{C}$ mineralized to ${ }^{14} \mathrm{CO}_{2}$ ) was calculated from the concentration of ${ }^{14} \mathrm{CO}_{2}$ 
in effluent water, specific activity of the detritus and flow rate through the chamber (Tenore et al., 1979). The amount of detritus mineralized over the course of an experiment was determined by plotting mineralization as a function of time and integrating the area under the curve.

The Wilcoxon test was used to examine differences between treatments. With 2 replicates per treatment, the lowest P-value tabulated is 0.13 for the case where both replicates of Treatment $A$ are greater than both replicates of Treatment $B$.

\section{RESULTS}

\section{Nematode Density}

Mineralization rates in control chambers (no nematodes present) were $\sim 25 \mu \mathrm{g} \quad \mathrm{C}$ detritus mineralized $h^{-1} ;<6 \%$ of the initial dry wt was mineralized over $1 \mathrm{wk}$ (Fig. 1). With $0.01 \times 10^{6}$ nematodes $\mathrm{m}^{-2}$, maximum mineralization rates were

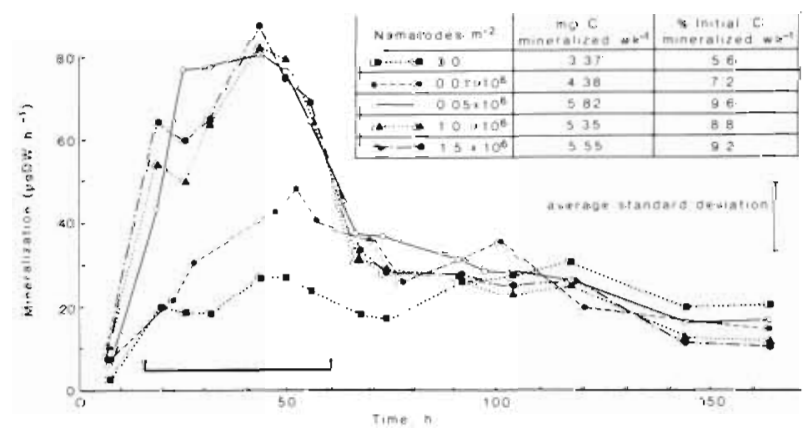

Fig. 1. Carbon mineralization in chambers containing $300 \mathrm{mg}$ dry wt Gracilaria detritus and various densities of Diplolaimella chitwoodi. Each line is the mean for 2 chambers. Brackets enclose time-span where treatments are significantly $(P=0.13)$ different

increased by $100 \%$ relative to controls and the initial dry wt increased to $7.2 \%$. With natural densities 0.05 to $1.5 \times 10^{6}$ nematodes $\mathrm{m}^{-2}$ ) maximum mineralization was $>300 \%$ greater than controls and the amount mineralized $w^{-1}$ was $8.8-9.6 \%$.

\section{Particle Size}

Presence of nematodes $\left(0.5 \times 10^{6} \mathrm{~m}^{-2}\right)$ increased the maximum mineralization rate and the amount mineralized $w^{-1}$ relative to controls for both large (250 to $308 \mu \mathrm{m})$ and small $(63$ to $100 \mu \mathrm{m})$ particle sizes of Gracilaria detritus (Fig. 2). The presence of nematodes caused greater differences in mineralization rate than
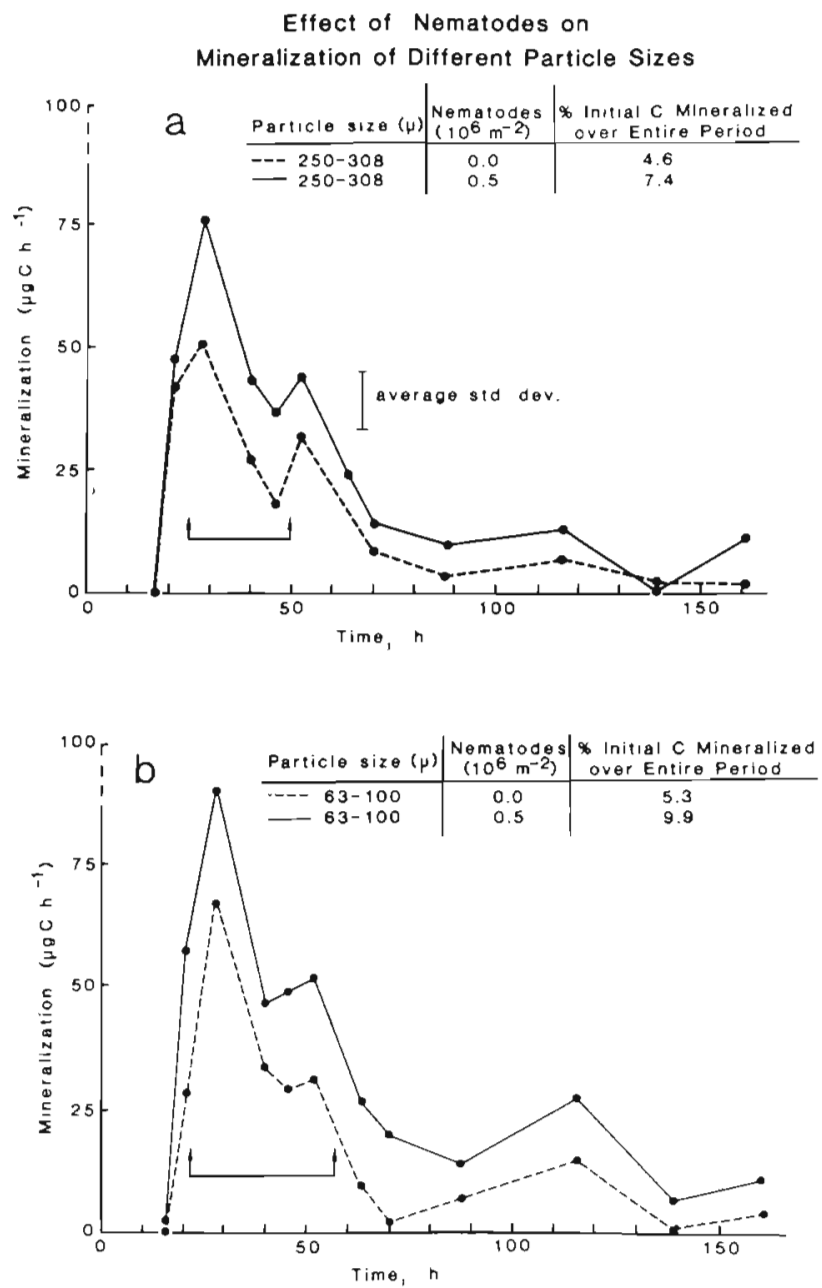

Fig. 2. Carbon mineralization of $50 \mathrm{mg}$ dry wt of 2 particle sizes of Gracilaria detritus with and without Diplolaimella chitwoodi. See also legend of Fig. 1

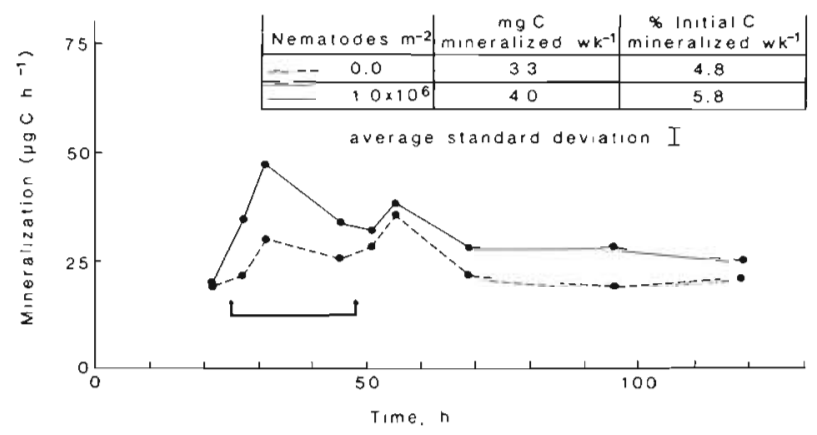

Fig. 3. Carbon mineralization of $300 \mathrm{mg}$ dry wt of Spartina detritus with and without Diplolaimella chitwoodi. See also legend of Fig. 1

the differences in particle size. Presence of nematodes increased maximum mineralization roughly $25 \%$ while mineralization of large vs. small particles was only slightly different. Amount of detritus mineralized 
$\mathrm{w}^{-1}$ was $25 \%$ higher with nematodes compared to no nematodes for both particle sizes. The amount mineralized $w^{-1}$ was roughly the same for large vs. small particles in control chambers.

\section{Spartina detritus}

The presence of $1.0 \times 10^{6}$ nematodes $\mathrm{m}^{-2}$ increased maximum rate of mineralization of Spartina detritus by $50 \%$ relative to no nematodes and amount mineralized $\mathrm{w}^{-1}$ by $20 \%$ (Fig. 3). The initial dry wt of Spartina detritus was $300 \mathrm{mg}$, and so is comparable to the results of 'nematode density' experiments. Rates of mineralization in control chambers were roughly the same for the 2 types of detritus (cf. Tenore et al., 1979; $0 \% \mathrm{~N}$ supplement). Mineralization of Spartina in the presence of nematodes was slower than mineralization of Gracilaria in the presence of nematodes.

\section{DISCUSSION}

Nematode densities in detritus-based systems average $10^{6}$ individuals $\mathrm{m}^{-2}$ (Coull and Bell, 1979) with 'deposit-feeders' such as Diplolaimella being the numerically dominant trophic type (Levy and Coull, 1977). The results show that these densities potentially double the rate of detrital carbon mineralization. Caution must be used when extrapolating from laboratory results to field conditions. For example, mixed communities of meiofauna might not exhibit the same results or mineralization may be limited by lack of oxygen. Even so, the potential magnitude of this nematode effect is a significant fraction of benthic carbon flow.

Presence of nematodes increased mineralization rate of 2 particle sizes, indicating that the observed increase was not specific to 1 particle size. Moreover, nematodes had a greater effect ( $25 \%$ increase) on mineralization rate than the difference in particle size. Although it is dogmatic that small particles decompose faster than large particles (Godshalk and Wetzel, 1978), there are no direct unequivocal measurements of weight loss from small vs. large particles in this size range. Therefore, nematodes must be considered at least as important as particle size differences when examining factors that affect rates of detritus mineralization.

Detrital source (derived from vascular vs. non-vascular plants) is also considered significant in controlling rates of decomposition (Tenore, 1977). There was no difference in mineralization rate of Gracilaria vs. Spartina detritus in the absence of nematodes (Figs. 1 and 3 ; see also Tenore et al., 1979). Nematodes increased mineralization of Spartina detritus but to a lesser degree than they increased mineralization of Gracilaria. Gracilaria detritus is of higher nutritional quality (Tenore, 1981; Hanson, submitted; Findlay, submitted). and therefore it is predictable that nematodes would exert a greater influence (whatever the mechanism) on Gracilaria mineralization relative to Spartina. Apparently, a larger proportion of Gracilaria detritus is immediately 'available' (i.e. is susceptible to rapid mineralization) whereas Spartina detritus must be aged for months before it reaches maximum 'availability' (Tenore and Hanson, 1980). Rates of mineralization in the absence of nematodes were roughly the same for Spartina and Gracilaria implying that this labile fraction in Gracilaria is not necessarily mineralized faster than the labile fraction in Spartina. These experiments used $3 \mathrm{~d}$ aged detritus; over longer time spans peak mineralization of Gracilaria occurs after $40 \mathrm{~d}$ of aging whereas peak mineralization of Spartina occurs after $150 \mathrm{~d}$ of aging (Tenore and Hanson, 1980). However, changes in extrinsic regulatory factors such as presence of nematodes or added nitrogen (Tenore et al., 1979) do lead to immediate differences in mineralization of Gracilaria vs. Spartina. The important point is that immediately 'available' detritus (Gracilaria) is much more susceptible to stimulation of mineralization by, for example, nematodes or nitrogen than is 'refractory' detritus (Spartina).

Temporal aspects of detrital decomposition may be complex and these experimental systems are not intended to represent an equilibrium or steady-state condition. It appears that nematodes change the timecourse of carbon mineralization. Apparently, there is a labile pool of carbon which is rapidly mineralized and depleted in the presence of nematodes (Fig. 1). In the absence of nematodes, this same pool is mineralized at a slower rate.

The actual mechanism by which nematodes enhance mineralization is unknown. Nematode-respired $\mathrm{CO}_{2}$ represents less than $4 \%$ of the carbon mineralization of Gracilaria in chambers with $10^{6}$ nematodes $\mathrm{m}^{-2}$ (assuming Diplolaimella chitwoodi respires at twice the maximum rate reported in Gerlach, 1971). Nematode respiration is a larger proportion of total mineralization of Spartina but still does not account for the increase in $\mathrm{CO}_{2}$ production in the presence of nematodes. Apparently, nematodes increase microbial activity, thereby increasing carbon mineralization.

The observed increase in carbon mineralization due to the presence of nematodes will decrease the standing stock of detrital carbon available to other detritivores. Although this in itself should decrease production, concurrent changes in microbial biomass and/or turnover may in fact increase the nutritional quality of 
the detritus (Ward and Cummins, 1979). For detritus such as seaweeds, which are directly available to consumers, it is quite likely that increased mineralization would decrease overall production. For instance, the population growth rate of Diplolaimella chitwoodiwas slower at low vs. high ratios of seaweed detritus but population growth was unaffected by low vs. high rations of Spartina detritus (Findlay, submitted).

Microbes, in the presence of nematodes, mineralize seaweed detritus faster than Spartina detritus (Figs. 1 and 3). Therefore, competition may occur between microbes and nematodes for Gracilaria detritus. Conversely, for more refractory detrituses such as Spartina or Zostera, the effect of nematodes on the microbial community may lead to an enhancement of microbial and/or consumer production. In either case, nematodes probably play a significant role in regulating the direction and magnitude of detrital carbon flow.

There is a long-standing discussion over the significance of nematodes and other meiofauna as food for higher trophic levels (e.g. Sikora, 1977) vs. their importance as regenerators of otherwise unavailable nutrients (Marshall, 1970; Lasserre et al., 1976; Tietjen, 1980). The present results demonstrate: Diplolaimella chitwoodi can play a central role in regulating carbon mineralization (microbial activity) that will indirectly affect other aspects of benthic carbon flow. The significance of nematodes in natural systems probably lies in their coupling and interactions with the microbial community. Consequently, because microbes are the most important component of marine benthos, factors such as nematodes, that affect microbial abundance and/or activity will play a larger role in benthic carbon flow than would be expected on the basis of nematode biomass or production.

Acknowledgements. Thanks are due to Dr. Roger Hanson and Bruce Dornseif for technical assistance. Drs. David Menzel, Neal Phillips, James Porter, Karen Porter, John Tietjen and Richard Wiegert reviewed and improved the manuscript. Bruce Hopper identified the nematode.

\section{LITERATURE CITED}

Barsdate, R. J., Prentki, R. J., Fenchel, T. (1974). Phosphorus cycle of model ecosystems: significance for decomposer food chains and effect of bacterial grazers. Oikos 25: 239-251

Briggs, K. B., Tenore, K. R., Hanson, R. B. (1979). The role of microfauna in detrital utilization by the polychaete, Nereis succinea (Frey and Leuckhart). J. exp. mar, Biol. Ecol. 36: 225-234

Cammen, L. M. (1980). The significance of microbial carbon in the nutrition of the deposit feeding polychaete, Nereis succinea. Mar. Biol. 61: 9-20

Christian, R. R., Wetzel, R. L. (1978). Interaction between substrate, microbes and consumers of Spartina detritus in estuaries. In: Wiley, M. (ed) Estuarine interactions. Academic Press, London, pp. 93-114

Cooper, D. C. (1973). Enhancement of net primary productivity by herbivore grazing in aquatic laboratory microcosms. Limnol. Oceanogr. 18: 31-37

Coull, B. C., Bell, S. S. (1979). Perspectives of marine meiofaunal ecology. In: Livingston, R. J. (ed.) Ecological processes in coastal and marine systems. Plenum Publ. Corp., New York, pp. 189-216

Fenchel, T. (1970). Studies on the decomposition of organic detritus derived from the turtle grass Thalassia testudinum. Limnol, Oceanogr. 15: 14-20

Fenchel, T. (1977). Aspects of the decomposition of seagrasses. In: McRoy, C. P. and Helfferich, C. (eds.) Seagrass ecosystems. Marcel-Dekker, Inc., New York, pp. 123-146

Gerlach, S. A. (1971). On the importance of marine meiofauna for benthic communities. Oecologia 6: 176-190

Godshalk, G. L., Wetzel, R. G. (1978). Decomposition of aquatic angiosperms. III. Zostera marina L. and a conceptual model of decomposition. Aquat. Bot. 5: 329-354

Gosselink, J. G., Kirby, C. J. (1974). Decomposition of salt marsh grass, $S$ alterniflora. Limnol. Oceanogr. 19: 825-832

Haines, E. B., Hanson, R. B. (1979). Experimental degradation of detritus made from salt marsh plants Spartina alterniflora Loisel, Salicornia virginia L., and Juncus roemerianus Scheele. J. exp. mar Biol. Ecol. 40: 27-40

Hargrave, B. T. (1970). The effect of a deposit-feeding amphipod on the metabolism of benthic microflora. Limnol. Oceanogr. 15: 21-30

Lasserre, P., Renaud-Mornant, J., Castel, J. (1976). Metabilic activities of meiofauna communities in a semi-enclosed lagoon. Possibilities of trophic competition between meiofauna and mugilid fish. 10th European Marine Biology Symposium, Vol. 2. Universa Press, Wetteren, pp. 393-414

Levy, R. V., Coull, B. C. (1977). Feeding groups and size analysis of marine meiobenthic nematodes from South Carolina, USA. Vie Milieu 27: 1-12

Marshall, N. (1970). Food transfer through the lower trophic levels of the benthic environment. In: Steele, J. H. (ed.) Marine food chains. Oliver and Boyd, Edinburgh, pp. $52-66$

Pamatmat, M. M. (1977). Benthic community metabolism: a review and assessment of present status and outlook. In: Coull, B. C. (ed.) Ecology of marine benthos. University of South Carolina Press, Columbia, pp. 89-111

Robertson, A. I., Mann, K. H. (1980). The role of isopods and amphipods in the initial fragmentation of eelgrass detritus in Nova Scotia, Canada. Mar. Biol. 59: 63-69

Sikora, J. P., Sikora, W. B., Erkenbrecher, C. W., Coull, B. C. (1977). The significance of carbon, ATP and calories of meiobenthic nematodes in partitioning benthic biomass. Ecology 44: 7-14

Sikora, W. B. (1977). The ecology of Palaemonetes pugio in a southeastern salt marsh ecosystem with particular emphasis on production and trophic relationships. Ph. D. thesis, University of South Carolina, Columbia

Smith, K. L., Burns, K., Teal, J. (1972). In situ respiration of benthic communities in Castle Harbor, Bermuda. Mar. Biol. 12: 196-199

Teal, J. M. (1962). Energy flow in the salt marsh ecosystem of Georgia. Ecology 43: 614-624

Tenore, K. R. (1977). Utilization of aged detritus derived from different sources by the polychaete. Capitella capitata. Mar. Biol. 44: 51-55 
Tenore, K. R. (1981). The effect of organic nitrogen and caloric content on detrital utilization by the deposit-feeding polychaete, Capitella capitata. Estuar. coast. Shelf Sci. 12: $39-47$

Tenore, K. R., Hanson, R. B. (1980). Availability of detritus of different types and ages to a polychaete macroconsumer, Capitella capitata. Limnol. Oceanogr. 25: 553-558

Tenore, K. R., Hanson, R. B., Dornseif, B. E., Wiederhold, C. (1979). The effect of organic nitrogen supplement on the utilization of different sources of detritus. Limnol. Oceanogr. 24: 350-355
Tenore, K. R., Tietjen, J. H., Lee, J. J. (1977). Effect of mejofauna on incorporation of aged eelgrass detritus by the polychaete, Nepthys incisa. J. Fish. Res. Bd Can. 34: 563-567

Tietjen, J. H. (1980). Microbial-meiofaunal interrelationships: a review. In: Microbiology 1980. American Soc. for Microbiology, Washington, pp. 135-138

Ward, G. M., Cummins, K. W. (1979). Effects of food quality on growth of a stream detritivore, Paratendipes albimanus (Meigen) (Diptera: Chironomidae) Ecology 60: 57-64

This paper was presented by Dr. G.-A. Paffenhöfer; it was accepted for printing on January 15, 1982 